\title{
Genidentity and Topology of Time: Kurt Lewin and Hans Reichenbach*
}

\author{
Flavia Padovani ${ }^{\dagger}$
}

\begin{abstract}
In the early 1920s, Hans Reichenbach and Kurt Lewin presented two topological accounts of time that appear to be interrelated in more than one respect. Despite their different approaches, their underlying idea is that time order is derived from specific structural properties of the world. In both works, moreover, the notion of genidentity-i.e., identity through or over time-plays a crucial role. Although it is well known that Reichenbach borrowed this notion from Kurt Lewin, not much has been written about their relationship, nor about the way Lewin implemented this notion in his own work in order to ground his topology. This paper examines these two early versions of the topology of time, and follows the extent of Lewin's influence on Reichenbach's proposal.
\end{abstract}

Keywords: Genidentity, topology of time, causal theory of time, relativized a priori, Kurt Lewin, Hans Reichenbach.

\section{Introduction}

Kurt Lewin and Hans Reichenbach have been central figures in the birth of logical empiricism as well as in the Berlin Group. As with many of their colleagues, their acquaintance goes back to the time of their involvement within the German youth movement known as "Freistudentenschaft", before World War I. At that time, they had close contact on matters related to their curriculum of studies, as we shall see

\footnotetext{
${ }^{*}$ A revised version of this paper will appear in The Berlin Group and the Philosophy of Logical Empiricism, Boston Studies in the Philosophy and History of Science, edited by Nikolay Milkov and Volker Peckhaus.

${ }^{\dagger}$ CPNSS, London School of Economics; English \& Philosophy Department, Drexel University. E-mail: F.Padovani@1se.ac.uk
} 
in Sect. 2. In the early 1920s, they were among those who tackled the issue of the definition of time order. Starting from different considerations, they developed two original accounts of the topology of time, which display interesting affinities. In Sect. 3, I will compare these accounts and thus address some historical and theoretical questions they raise.

Before going on, let us first clarify in what sense we will use the term "topology" in this paper. Here, this term is referred not to the usual notions of topology but rather to the objective system of relations and coincidences of point-events that can be established before any metrical determination, thereby independent of any arbitrariness. In fact, both Reichenbach and Lewin were engaged in the attempt to derive the truth of a number of temporal propositions from the occurrence of characteristic and elementary phenomena in the world. The topological relations defined in their works did not merely portray some representational artefact. On the contrary, what these two constructions intended to capture was an "ultimate fact" of nature. ${ }^{1}$

A common feature of these two accounts is that they both crucially make useimplicitly or explicitly-of the notion of "genidentity" (i.e., identity through/over time). The basic questions they address can be sketched as follows: 1) When are two events genidentical, that is, involving the same thing? 2) When are two genidentical events one before the other, or else simultaneous? 3) When are two non-genidentical events one before the other, or else simultaneous? The critical element of divergence is that Reichenbach aimed to illustrate the temporal order of physically possible events, whereas Lewin dealt with the ordering of actual events.

Reichenbach first mentioned the concept of "genidentity" in his Relativitätstheorie und Erkenntnis apriori (1920), where it was regarded as a synthetic, yet revisable a priori principle. In this book, genidentity represented a very special principle of coordination of formal structures to reality required in order to identify an object as the selfsame object in the passage through time. In the shift toward a conventionalist stance that Reichenbach notoriously embraced soon after 1920, coordinating principles would be turned into either coordinative (conventional) definitions or epistemological and methodological principles. However, the principle of genidentity was dropped in this passage. In both his "Bericht" (1921b) and Axiomatik (1924), Reichenbach took the notion of "light signal" as the basis from which to derive the topological properties of (space-)time. By doing so, the key idea behind the principle of genidentity was dissolved into what will be later known as "the mark principle" (Sect. 3.2).

In Der Begriff der Genese (1922), Lewin used the notion of genidentity primarily as a sort of analytic tool to pursue his project of comparative sciences. In

\footnotetext{
${ }^{1}$ Reichenbach (1928/1958, 285). Cf. also Ryckman (2007, 205 ff.).
} 
the following publication on this topic, "Die zeitliche Geneseordnung" (1923a), he addressed the question of the possibility of erecting a temporal topology only on the basis of certain most elementary features of reality. Thus, he proposed a topological account of time by taking the existential relation implied by genidentity as primitive (Sect. 3.1). With respect to Reichenbach's attempt, Lewin's approach turned out to involve a more fundamental level of analysis that Reichenbach should have considered given his claim that his axiomatic construction starts with the most elementary facts. In their correspondence of the early 1920s, which we shall briefly analyse in 3.2.2, Lewin will argue that Reichenbach's notion of "first signal" can, and actually should, be decomposed and reduced to its constituents. According to Lewin, the notion of "identity through time" as an existential relation is a primitive notion that must be presupposed even before considering any physical process, such as a light signal. The concept of signal, to Lewin's mind, already conveys the sense of some thing propagating through time and, therefore, requires a prior principle of temporal individuation that his formalised concept of genidentity is meant to provide.

As a result of this exchange, the principle of genidentity will be reintroduced in Reichenbach's work, notably in his Die Philosophie der Raum-Zeit-Lehre (1928), where it will be surprisingly defined as an "empirical principle" (Sect. 4). In this conclusive Section, I will also briefly emphasise the importance of Lewin's influence on Reichenbach's first attempt to define the direction of time in "Die Kausalstruktur der Welt" (1925), and I will finally suggest that this principle still holds a peculiar position in Reichenbach's later work, more precisely as a constitutive principle.

\section{Crossed Destinies: from the Youth Movements to the Erlangen Meeting, through the Wireless Teleg- raphy}

Like many of their German contemporaries, while they were attending university, Lewin and Reichenbach took part in the activities of a student movement known as Freistudentenschaft. It was essentially a libertarian, egalitarian, anti-racist, antiauthoritarian, estheticist, and non-traditionalist movement, in certain respects also anti-militarist. Oriented by the idea of the moral self-determination of the individuals and of the freedom of directing one's own future, this movement stood against any form of dogmatism, be it scholastic, religious, philosophical, political or institutional. ${ }^{2}$ Like Lewin, Reichenbach joined the Freistudentenschaft around

\footnotetext{
${ }^{2}$ For an analysis of the birth and development of the German student movement, cf. Wipf (2004). To have an idea of Reichenbach's active contribution to the activities of this group, see
} 
1910, and his adhesion to the ideals of this group later developed into a prominent political commitment with socialist groups. ${ }^{3}$

Reichenbach's relation to Kurt Lewin dates back to at least 1911. It was likely on the occasion of the 1911 national Berlin meeting of this association that they must have first met. ${ }^{4}$ In the summer of that year, they started a correspondence on matters related to education in German universities. In the only letter of this early exchange that was preserved, ${ }^{5}$ Lewin warmly responded to what must have been Reichenbach's inquiry about the situation of scientific psychology (wissenschaftliche Psychologie) in German universities, especially in Berlin, Munich and Göttingen, i.e., the three universities where Reichenbach actually spent the following four years. ${ }^{6}$

also Wipf (1994) and Maria Reichenbach's introductory remarks to Reichenbach (1978: Vol. I, 91-101). An overview of Lewin's involvement can be found in Ash (1995, 265 ff.).

${ }^{3}$ In 1918, Reichenbach drew the programme of the socialist student party and published a number of pamphlets distributed in alternative circles. Cf. Reichenbach (1978: Vol. I, 132-185).

${ }^{4}$ Reichenbach presented two papers that would be published as (1911a) and (1911b).

${ }^{5}$ In what follows, I will mainly refer to material from the Hans Reichenbach Collection (HR) available at the Archives for Scientific Philosophy (ASP) of Pittsburgh and Konstanz, except from one letter from the Moritz Schlick Collection at the Wiener Kreis Stichting in Amsterdam. All the material is quoted by permission of the University of Pittsburgh and the Wiener Kreis Stichting. All rights are reserved.

${ }^{6}$ Lewin recommended Reichenbach to go to Munich rather than to Berlin, and to refer to the local section of the free student body, motivating his advice on the lack of interesting professors in Berlin, on the one hand, and on the opportunities that the Munich surroundings offered for skiing on the other ["Berlin kann ich Ihnen gar nicht empfehlen, wohl aber München für den Winter. Treten Sie in die Abteilung der M.[ünchener] Fr.[eien]St.[udentenschaft] ein [...] und lernen Sie skilaufen." (ASP, HR 023-13-31, Lewin to Reichenbach, 29 September 1911)]. To be sure, Lewin described the situation of the studies in psychology in Germany as not exciting at all. For example, Theodor Lipps is portrayed as an old man, almost never teaching and in general unable to deliver good lectures, despite having written a good textbook. Alexander Pfänder, student of Lipps, is presented as a good philosopher, yet with too little knowledge of scientific psychology (von naturwissenschaftlichen Psychologie). Georg Elias Müller appears to be one of the few having a scientific approach and as well as being truly engaged in teaching specific chapters of psychology. In Lewin's view, Hans Rupp was not particularly good as teacher, but provided the students with useful exercises, so that he seemed the only one really promoting psychology in Berlin. Curiously, the worst picture Lewin drew is that of one his own future supervisor, Carl Stumpf, described as teaching poorly and boringly ["ich kann Sie versichern, er taugt nichts und ist obendrein sprachlich langweilig"]. These discouraging words notwithstanding, besides philosophy and traditional mathematical-physical classes, Reichenbach will attend Stumpf's course Psychologie mit Demonstrationen and Rupp's Experimentelle Übungen zur Psychologie in the 1911-12 winter semester in Berlin (ASP, HR 041-09-16). He will instead go to Munich the following academic year, and indeed become a member of the local division of the Freie Studentenschaft, with a specific focus on psychological research. Whether and how Lewin was influential in making Reichenbach turn at first directly to philosophy is difficult to say. But it may be a consequence of Lewin's positive appreciation of Müller if Reichenbach first (unsuccessfully) tried to have him as his supervisor in Göttingen. 
Both Lewin and Reichenbach attended Ernst Cassirer's and Carl Stumpf's lectures at the University of Berlin at different times, and were variously influenced by them. As an experimental psychologist, Stumpf was a pioneer also in experimenting with tones, and in the psychology of acoustic perception-teachings that would soon reveal to be important for both of them. After a short period on the Russian front line, Reichenbach served for almost two years in the signal corps of the German army in Neuruppin, not far from Berlin. ${ }^{7}$ Like Reichenbach, Lewin volunteered and served in the army, until he was injured in combat in $1917 .{ }^{8}$ When he was transferred near Berlin, he was assigned to the construction of devices for sound measurement. Respectively, they brought their scientific and technical competences in the context of the new situation that was originating at the front, where various scientific fields proved to be of pivotal importance in solving a variety of military problems. Also psychologists contributed to this endeavour especially by providing skill tests in order to select the most suitable individuals for each specific military task. ${ }^{9}$ It is in the spirit of these synergies that in this period Reichenbach collaborated with Kurt Lewin and Otto Lipmann-one of the first to apply the new research tendencies in psychology to the industrial problems, and co-founder, with William Stern, of the Zeitschrift für angewandte Psychologie — on the development of an aptitude test for radio telegraphists. ${ }^{10}$

During the years 1918-1920, Lewin and Reichenbach were both in Berlin. Reichenbach was employed in the Huth radio industry, ${ }^{11}$ while attending Einstein's lectures on statistical mechanics, special and general relativity. ${ }^{12}$ Lewin

\footnotetext{
${ }^{7}$ Cf. Gerner (1997, ch. 2.3.)

${ }^{8}$ See Marrow $(1969,10-11)$.

${ }^{9}$ Mitchell Ash illustrates this state of affairs in the following way: "The First World War saw the emergence of the technological battlefield, and it also marked a turning point in the interaction of technology and basic science. In numerous ways scientists demonstrated the usefulness of basic research by employing laboratory instruments and techniques to solve military problems, from the development of sound-ranging devices in physics to that of poison gas in chemistry. Psychologists in Germany participated in this process by adapting psychophysical measurement to skills testing for the selection of communications specialists, pilots, and drivers. The focus of these efforts was on the 'human factor' - on the human organism as a functioning part of a machine. Practitioners in the new field called 'psychotechnics' searched for the machine operators whose skills were best suited to the task in question-whose reactive idiosyncrasies, that is, interfered least with efficient functioning." Ash $(1995,188)$.

${ }^{10}$ This document, entitled "Entwurf zu einer Eignungsprüfung für Funkentelegraphisten" and signed by Lewin, Lippmann, and Reichenbach, was completed in 1917 (ASP, HR 024-16-02).

${ }^{11}$ His work focussed on particular amplifying valves. See, for instance, some of his more technical writings of the period like "Statistisches Verfahren zur Beurteilung von Verstärkerröhren" (ASP, HR 044-03-21), "Zur Theorie der Verstärkerröhren" (ASP, HR 044-03-23), and "Beschreibung des Huth'schen Verstärkers L. 43 F. 25m Niederspannung-Verstärker” (ASP, HR 044-03-25).

${ }^{12} \mathrm{Cf}$. Reichenbach's five corresponding lecture notebooks (ASP, HR 028-01-01/05), as well as Gerner (1997, ch. 2).
} 
was a member of the Institute of Psychology, around which, in contrast to the traditional Wundtian approaches, Stumpf gathered the future leading figures in this new direction in experimental and applied psychology, like Wolfgang Köhler, Kurt Koffka, and Max Wertheimer, all embracing the ideas of Gestalt psychology. At that time, Lewin was working on a lengthy monograph on the concept of "genetic series" that he unsuccessfully tried to submit as his Habilitation thesis to obtain the qualification for teaching philosophy at the University of Berlin. ${ }^{13}$ The thesis would not be published until 1922, as we shall see in the next section.

After being bestowed the teaching Habilitation for physics with his Relativitätstheorie und Erkenntnis apriori (1920), Reichenbach was first appointed assistant to the physicist Erick Regener, and soon after "Privatdozent" (a sort of associate professor) at the Stuttgart Technische Hochschule. During the entire period in Stuttgart, Reichenbach kept in touch with Lewin for discussions concerning not only philosophical issues, but also one of the most important events in the early phases of logical empiricism, the famous Erlangen conference of 1923, in which both Reichenbach and Lewin participated. One of the issues discussed during that meeting was the creation of a journal for exact philosophy that was only realised with the publication of the first issue of Erkenntnis in 1930. Lewin was one of the most active among those who were engaged in the organisation of this periodical, as an intense correspondence with Reichenbach demonstrates. ${ }^{14}$ Other important topics of debate were the comparative theory of sciences, the axiomatic method in physics, and the topology of time. Each of these discussions was of clear significance to both of them, and they would lead to further exchanges of views. Despite their different approach, their topological accounts of time will have a common denominator: the use-explicit or not—of the principle of genidentity as fundamental.

\section{The Many Faces of Genidentity}

The term "genidentity" was coined by Lewin in the Habilitation thesis that he wrote (but did not publish) in 1920, but was officially introduced in 1922 in (what seems to be) the revised version of this thesis that was published under the title Der Begriff der Genese in Physik, Biologie und Entwicklungsgeschichte (1922). To be sure, the first time this term appears in a publication is in Reichenbach's 1920 book on relativity theory. In this book, Reichenbach explicitly refers to

\footnotetext{
${ }^{13}$ Carl Stumpf also supervised his Habilitation thesis. References to the history of this monograph, and the difficulties that Lewin had to face in order to receive that qualification with this treatise can be found in Métraux's introduction to Lewin (1983) and in Métraux (1992).

${ }^{14}$ From July 1923 to October 1924 they exchanged about twenty letters, almost exclusively related to the creation of their journal. See ASP, HR 016-36-07/26.
} 
Lewin's Die Verwandtschaftsbegriffe in Biologie und Physik und die Darstellung vollständiger Stammbäume (1920)-where this term actually does not appear-and to another book by Lewin seemingly dealing with the order type of genetic series in various domains. Reichenbach refers to the latter book as being entitled Der Ordnungstypus der genetischen Reihen in Physik, organismischer Biologie und Entwicklungsgeschichte. However, this work does not appear to have ever been published, although Reichenbach even names a publisher (Borntraeger, Berlin). Presumably, this was the original title of Lewin's unpublished thesis, which Reichenbach must have read in draft while they were both in Berlin. In these early years, they were certainly very close, and most likely often discussing their respective researches. It is not a coincidence, in fact, if a few years later Reichenbach recalled that Lewin, along with Einstein, were the two persons to whom he showed the drafts of his relativity book. ${ }^{15}$ In this work, he borrows the concept of genidentity from Lewin, but develops his account in a different fashion.

In what follows, I shall compare the meanings and roles assigned to genidentity in the works of the two authors. We will see how the differences account for two distinct topologies of time.

\subsection{The Concept of Genidentity in Kurt Lewin}

Lewin's first publication to tackle the problem of the order type deriving from particular sequences called "genetic" is Die Verwandtschaftsbegriffe in Biologie und Physik und die Darstellung vollständiger Stammbäume. ${ }^{16}$ This is a study of some specific relationships in different sciences, namely biology and physics (where physics is interpreted in a very loose sense, including — and at times, identifying with-chemistry) $)^{17}$ and represents his first treatise of comparative sciences.

The gist of Lewin's work is to identify a certain (genetic) type of order (Ordnungstypus) in these sciences, an order that is characteristically exemplified, for instance, by the relationship of relatedness in biology and that of affinity in chemistry. Lewin shows how these relationships can be represented through family

\footnotetext{
${ }^{15}$ In some autobiographical notes written in 1927, Reichenbach reconstructed the circumstances in which he wrote his own Habilitation thesis with the following words: "Im Februar (oder März) 1920 beschloss ich, meine Habilitationsschrift zu schreiben. Ich hatte in den Monaten vorher Relth. gearbeitet, auch nach Weyl; den Grund hatte ich schon in 1917-1918 in Vorlesungen bei Einstein gelegt, aus welchen meine Kenntnis der Th.[eorie] herrührt.[...] Die Schrift ist in etwa 10 Tagen niedergeschrieben. Das M[anu]s[kript] wurde dann abgetippt. Ich zeigte es Einstein u. Lewin. Durch Berliners Vermittl[un]g kam es zu Springer. Erschienen ist es im Sept. 1920, zum Naturforschertag." ASP, HR 044-06-23.

${ }^{16}$ Lewin (1920). The foreword is dated March 31, 1920.

${ }^{17}$ As Lewin declares in the first lines, “[i]n der Physik, worunter hier die Physik im weiteren Sinne des Wortes verstanden wird, wird der Begriff der Verwandtschaft im allgemeinen für die chemische Verwandtschaft benutzt.” Lewin $(1920,5)$.
} 
trees. In particular, analysing biological pedigrees, he focusses on the genealogical relation, necessarily asymmetric, between ancestors and progeny, which he terms "genetic series" (Genetische Reihe). In general, a genetic series is an effectual relation of antecedency of the type "being-such-as-to-have-come-forthfrom". ${ }^{18}$ Interestingly, Lewin's investigation is carried out with a sort of mereological approach in which the sequences are compared with the whole of the formations they belong to. ${ }^{19}$

In spite of the title of this essay, the corresponding relation of existence that could obviously be thought of in physics is not considered by Lewin. In one passage, though, he highlights an essential aspect that characterises the physical sequences, that is, their continuity and extension towards infinity along their both sides, which illustrates a relation of complete (restlos) derivation among each and every slice. ${ }^{20}$ What this type of derivation means is better specified by Lewin only in (1922) with the expression "complete physical genidentity", as we shall see below, p. 10 .

Lewin introduces and expounds on the notion of "genidentity" in Der Begriff der Genese (1922), where it is embedded in a much larger project of comparative sciences than the first research of 1920. More than underlining commonalities among sciences, Lewin's comparative approach also highlights the sciences' specificities. What is compared and studied are not similar objects (Objecte) per se but objects displaying an equivalence from the viewpoint of the theoretical knowledge we have of them, that is, what he defines as "wissenschaftstheoretisch äquivalente" Objecte. ${ }^{21}$ The aim of this more extensive research is to show that,

\footnotetext{
18“Die Existentialbeziehung, die in der Biologie als Verwandtschaft bezeichnet wird, kann einmal zwischen Gebilden bestehen, die auseinander hervorgegangen sind, z. B. zwischen Kind und Eltern oder Großeltern, oder zweitens zwischen Gebilden, die gemeinsame Vorfahren oder Nachkommen besitzen, ohne selbst voneinander abzustammen. Auf die Existentialbeziehung zwischen Vorfahren und Nachkommen, das existentielle Auseinanderhervorgegangensein im Nacheinander, soll hier nicht näher eingegangen werden.” Lewin (1920, 20). The reference goes to the above-mentioned forthcoming more extended research.

${ }^{19}$ This approach will be cast in more formal terms in his following publication on this topic, Der Begriff der Genese (1922). Analyses and discussions brought up in mereological terms were quite frequent in Stumpf's circle. For an account of the theory of the whole/part relations in Stumpf and his school, cf. Smith \& Mulligan (1982).

20 "In der Physik handelt es sich, wie hier nicht weiter ausgeführt werden kann, um einen kontinuierlichen, beiderseits ins Unendliche gehenden Reihentypus. Es ist ein wesentliches Charakteristikum dieser Reihen kontinuierlich aufeinander folgender Schnitte, daß es auch zu jedem beliebig herausgegriffenen Teil eines Schnittes eine solche beiderseits unendliche Reihe von Schnitten gibt, mit denen er in der Beziehung des restlosen existentiellen Auseinanderhervorgegangenseins steht." Lewin $(1920,21)$.

${ }^{21}$ It goes without saying that the main source of inspiration for this approach is Cassirer's famous monograph Substanzbegriff und Funktionsbegriff (1910). As Lewin wrote in 1920: "Diese die Vergleichbarkeit begründende wissenschaftstheoretische Äquivalenz, die sich auf die ganze
} 
in spite of certain structural similarities that can be identified in such objects, they exhibit different modalities of application in the compared sciences. In 1922, this aim is pursued by investigating how the concept of genidentity functions and the way it acquires its meaning within various domains.

The concept of genidentity is again essentially characterised in mereological terms. Objects or events are temporally extended, thus their genetic series consists of a multitude of entities, representing their various phases at various times. According to Lewin, physical constructs (Gebilde) that have developed one from the other can be conceived as temporally distinct, so that we can define the relation of genidentity as the existential relation that holds between them. ${ }^{22}$ Here we won't follow Lewin's complex treatment of the multiplicity of relations that can be subsumed under this same concept. To just give an idea of some different but related notions of genidentity, let us take a classical example that Reichenbach also briefly mentions in his (1924c, 189). Between the egg and the hen there is a relation of biological genidentity in that they represent different stages of development of the same biological matter: they are slices of the same genetic series connecting the selfsame individual along a temporal sequence. From a physical viewpoint, though, they are not genidentical because the molecules composing them have changed. Besides, a physical genetic series can lead from the egg to the variety of other formations that can be developed from it, so it may also bring forth, say, a piece of cake.

These various ways of "cutting" reality into units reflect the different angles from which to analyse real objects or processes in temporal perspective. In (1922), Lewin introduces a different terminology to distinguish the multiplicity of genetic series, like the biological from the physical genidentity. For instance, the biological relation of genidentity between an individual and his or her descendants is defined as "avalgenidentity", whereas the relation of genidentity holding among successive temporal sections of individuals-whole organisms, but also cells-is called "individual genidentity". While the relations of genidentity used in these

Stellung der Vergleichsobjekte in den betreffenden Wissenschaften stützt, kann nicht durch irgendwelche äußerliche Übereinstimmungen ersetzt oder durch äußerliche Ungleichheiten widerlegt werden. Die wissenschaftstheoretische Äquivalenz bestimmter Begriffsgebilde oder Einteilungsprinzipien in verschiedenen Wissenschaften bedeutet daher auch umgekehrt noch keine völlige Gleichheit der betreffenden Vergleichsobjekte oder gar eine Identität der betreffenden Wissenschaften." Lewin (1920, 3). See also Lewin (1925).

22"Physikalische Gebilde, die zu verschiedenen Zeitmomente existieren, sollen also als eine Mehrheit von Gebilden aufgefaßt werden, nicht anders als gewisse räumlich verschiedene Gebilde. [...] Physikalische Gebilde, die auseinander hervorgegangen sind, müssen, abgesehen von anderen möglichen Unterschieden, jedenfalls zeitlich verschieden sein. Wir wollen, um Verwechslungen zu vermeiden, die Beziehung, in der Gebilde stehen, die existentiell auseinander hervorgegangen sind, Genidentität nennen. Dieser Terminus soll nicht anderes bezeichnen als die genetische Existentialbeziehung als solche.” Lewin (1922/1983, 60-62). 
domains may show some affinities, they do not share the same properties when implemented in different contexts. Every science represents a specific, closed network of interrelated concepts that cannot simply be extrapolated and applied within other networks. Hence, the passage from one science to the other implies an ideal partitioning of reality. ${ }^{23}$

For our discussion, the relation of physical genidentity is the most salient one, as it represents a good candidate to determine temporal sequences. We have seen above that in (1920) Lewin briefly mentions an important feature of sequences in physics, that is, the relation of complete derivation among genetic slices of physical events. This relation of complete derivation is now elaborated and presented as "complete genidentity". Roughly, the idea is that physical constructs are in a relation of complete genidentity when none of their own other parts stands in a relation of genidentity with some other construct. ${ }^{24}$ In general, the completeness (Restlosigkeit) of the physical, genidentical relation can be understood, Lewin explains, as typically presupposed by the activity of experimenting in physics, where it is ideally required that physical systems be in isolation from external disturbances. For cases where complete genidentity does not apply but an existential relation of partial antecedency can still be identified, Lewin speaks of "simple genidentity" (Genidentität überhaupt). Simple genidentity is the relation that holds between constructs that share at least one part correlated by complete genidentity. For example, consider the case of a piece of metal that is plunged into a liquid at a time $t_{1}$ and is found altered afterwards, say at a time $t_{2}$. If you then remove a part of the liquid, you will have to suppose that something of the metal that was partially dissolved in it has also been removed. Hence, the remains of the metal at the time $t_{2}$ will stand in a relation of complete genidentity with the parts of the metal they belonged to at the time $t_{1}$, but the whole formation cannot be accounted for through genidentical completeness. ${ }^{25}$

In general, physical genidentity does not consider qualitative differences in the properties of related objects, but mainly takes into account their temporal differ-

\footnotetext{
${ }^{23}$ Lewin (1922/1983, $131 \mathrm{ff}$.). For example, the relation of complete physical genidentity is characterised by: 1) continuity in the passage between the correlated constructs; 2) independence of the relation from the direction of the series (symmetry); 3) independence from the distance between the slices along a sequence; and 4) exclusion of a partially unconnected construct simultaneously existing with one of two completely genidentical slices that is simply genidentical with the other one. Cf. Lewin (1922/1983,89-90). Thus, complete physical genidentity has transitivity, temporal density, and continuity as properties, whereas avalgenidentity presupposes discontinuity, lack of density, and some further conditions for transitivity. See Lewin (1922/1983, $158 \mathrm{ff}$.).

24 "Ein physikalisches Gebilde $a_{1}$ ist restlos genidentisch mit $a_{2}$, wenn 1) im Zeitpunkt 1 kein zu $a_{1}$ teilfremdes physikalisches Gebilde (Teil eines Gebilde) existiert, das mit $a_{2}$ in Genidentitätsbeziehung steht, und wenn 2) im Zeitpunkt 2 kein zu $a_{2}$ teilfremdes physikalisches Gebilde (Teil eines Gebildes) existiert, das mit $a_{1}$ in Genidentitätsbeziehung steht." Lewin (1922/1983, 82).

${ }^{25}$ Lewin (1922/1983, 84 ff.).
} 
ences. Nonetheless, the order of genidentical formations cannot be traced back to a temporal order. The concept of genetic series is indeed more fundamental than the one of temporal order that can be drawn from it. ${ }^{26}$ This type of order is not to be understood in terms of an external order that can be used to determine temporal relations among objects or events. As a matter of fact, it captures an internal, immediate, and most fundamental relation of the objects (or events) considered. ${ }^{27}$ In this sense, it can be deemed a constitutive category (constitutive Kategorie) ${ }^{28}$ pertaining to the existence relation.

Consequently, physical genidentity gives rise to a specific type of order, namely the existential relationship expressed in the concept of the "one-after-the-other" (im Nacheinander). ${ }^{29}$ The idea behind this genetic type of order will be borrowed by Reichenbach as a model for a temporal topology, as we shall see in the next subsection. Interestingly, Lewin also addresses this question in his "Die zeitliche Geneseordnung" (1923a), where he proposes a temporal topology—still construed in mereological terms-based on the notion of a genetic series and time order of actual events. The theory of relativity, he explains in the introductory remarks, employs light signals for the determination of the temporal relations. In particular, for its construction it makes use of a specific property, constancy (Konstanz), of a specific physical process, the propagation of light. In the Minkowski system of world lines, the point of intersection of the event series is uniquely determined. Even so, for Lewin the assignment of all those world lines to concrete objects fundamentally relies on an existential relation. The subsumption under a specific world line actually depends on the relation of historical derivation (geschichtliche Herkunft) of an event from another and does not depend on other features like equal measure or energy. For this relation of historical derivation, expressed by a genetic series, all other determinations (measure, velocity, volume, and in general all physical values of the members of the series) are not decisive. The essential

\footnotetext{
26“[Die] Zeitverschiedenheit der Relata [bildet] eine notwendige Voraussetzung für das Vorliegen der physikalischen Genidentitätsbeziehung zwischen ihnen. Diese Verschiedenheit bezieht sich jedoch nicht auf solche mit der Zeit zusammenhängenden "Eigenschaften" wie die Geschwindigkeit, sondern lediglich auf die Verschiedenheit der Stellung des Gebildes innerhalb der Ordnung des Nacheinander. Es wird sich später zeigen, daß die Ordnung innerhalb der Reihen genidentischer Gebilde nicht auf die Zeitordnung zurückzuführen ist, sondern daß der Begriff der genetischen Reihe wahrscheinlich fundamentaler ist als der der Zeitordnung." Lewin (1922/1983, $65)$.

27“Der Ausdruck "Ordnungstypus" soll nicht bedeuten, daß es sich um subjektive, nicht gegebene, sondern gemachte Ordnungen handelt. Er wird vielmehr in einem aller Aktivität oder Passivität des Erkenntnissubjektes gegenüber völlig neutralen Sinne benutzt und besagt lediglich, daß die hier wesentlichen Verschiedenheiten der Existentialbeziehungen Verschiedenheiten der "inneren Geordnetheit" sind, und zwar weniger was den Grade als was den Typus der Ordnung anbelangt.” Lewin (1922/1983, 317).

${ }^{28}$ Lewin $(1922 / 1983,69)$.

${ }^{29}$ Lewin $(1922 / 1983,73)$. Cf. also above, footnote 18.
} 
one, according to Lewin, is the simple relation of existence that makes all other properties significant.

Thus, as a development of his previous research, Lewin focusses on the existential relation that grounds the concrete object's characteristic belonging to a specific world line. For instance, to determine the temporal succession of a real series, Lewin starts by defining the direction of the genetic series. Let $a_{n}$ and $a_{m}$ be distinct cuts (Schnitte) of a series. If $a_{n}$ has derived from $a_{m}$, we can characterise $a_{m}$ as "genetically earlier than" $a_{n}$, like in the first example of Figure 1, where the arrow indicates the direction of the formation. He then introduces Axiom I, which states that a cut of a genetic series occurs in this series only once. ${ }^{30}$ This means that a genetic series does not loop back on itself and that the chain cannot be closed. Obviously, a cause cannot be, at the same time, the result of its own effects. In this framework, the relation of cause to effect clearly does not cover the many meanings of genidentity. In general, we can speak of a cause only in association with a conjunction of events, not when considering one single event. $^{31}$

Up to now, we have dealt with genidentical sequences considered separately. In order to fulfil the declared aim of the paper, namely provide a definition of temporal order, the analysis must be extended to situations where several series interact. Hence, Lewin exploits the idea that temporal determinations can obtain where genetic series share some cuts or are linked by other commonly connected series. To begin with, a series can produce separate series through a "splittingoff" (Abspaltung) or can be observed as their "reunion" (Vereinigung), as shown in Figure 1 (second and third example, respectively). Besides, as we shall see, it can also split off into separate series and then reunite again.

There are cases of genetic series in which the direction of the sequence is rather obvious (e.g. from an actual egg to the hen resulting from it), but in physics the points along an existential world line do not unambiguously entail the idea of antecedency of one relatively to the other. Such instances motivate Lewin to broaden the concept of genetic series so as to embrace cases presenting a causal relation within a conjunction of events. To capture these cases, he introduces the notion of "genetic series of succession" (Genesefolgereihe), for which he also uses the term "causal series" (Kausalreihe). This type of series is characterised as follows: we have a genetic series of succession when there is a choice of cuts such that any two consecutive cuts are genidentical in the same direction, without the requirement that the other cuts be genidentical all among themselves. ${ }^{32}$ This

\footnotetext{
30“Axiom I: Ein Schnitt einer Genesereihe kommt in dieser Reihe nicht mehrmals vor." Lewin (1923a, 66).

${ }^{31}$ Thus, a stone at a time $b_{1}$ is not the cause of the stone being the same at a time $b_{2}$. Cf. Lewin (1922/1983, 72).

32“Eine Reihe, in der sich eine Anzahl von Schnitten so herausgreifen läßt, daß je zwei
} 

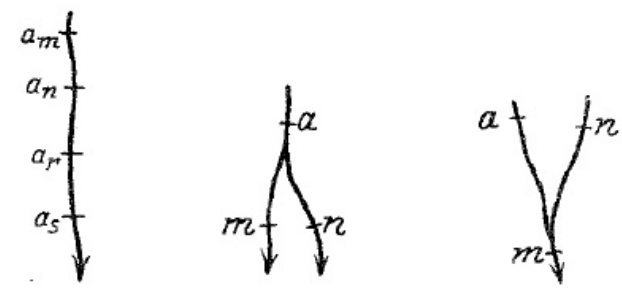

Fig. 1: Antecedency between multiple series cuts, splitting-off, and reunion of genetic series, Lewin (1923a, 69).

addition allows for the temporal comparison among series that haven't derived directly one from the other, but that are instead joined via other series. In this sense, the concept of Genesefolgereihe enables the univocal determination of a temporal order on the basis of the structural features of the nets realised by "interacting" series. Thus, Lewin introduces Axiom II which expresses the openness of causal chains by stating that a genetic series of succession does not lead back onto itself. This clearly represents an extension of the first Axiom onto the newly defined class of series. ${ }^{33}$ Finally, Lewin denotes as "temporal order of the genesis" (zeitliche Geneseordnung) any system-time which has been determined by means of the relationship of the "one-next-to-the-other" among genetic series of succession. $^{34}$

Besides the relation between two series that intersect or part at a certain time, particular importance is assigned to those series that play the role of "carriers" or "messengers" (Boten) connecting two separate series (Figure 2, first example). Their function is similar to that of a clock since they enable a comparison and thereby a univocal temporal determination between separate series.

As the second (carriers $V^{2}$ and $V^{3}$ ) and third example (direction of the arrows resulting from the two carriers' system intersecting at $x$ and $y$ with respect to the direction of the genetic series B) of Figure 2 show, these cases are inconsistent for they give rise to temporal relations among slices that imply the contradiction of Axiom II, the one asserting the impossibility of genidentical (therefore, temporal)

aufeinanderfolgende Schnitte genidentisch, und zwar in derselben Richtung genidentisch sind, ohne daß sämtliche Reihenschnitte untereinander genidentisch zu sein brauchen, heiße "Genesefolgereihe (G-Folgereihe). Die Zeitbeziehung ihrer Glieder heiße: "zeitlich früher" $(\rightarrow)$ und "zeitlich später" $(\leftarrow)$." Lewin (1923a, 67).

33“Axiom II: Eine Genesefolgereihe führt beim Fortschreiten in einer Richtung nicht in sich zurück." Lewin (1923a, 67).

34 "Ein Zeitsystem, das lediglich durch dieses Axiom über das Nacheinander in Genesefolgereihen bestimmt wird, sei als “zeitliche Geneseordnung” bezeichnet.” Lewin (1923a, 67). 

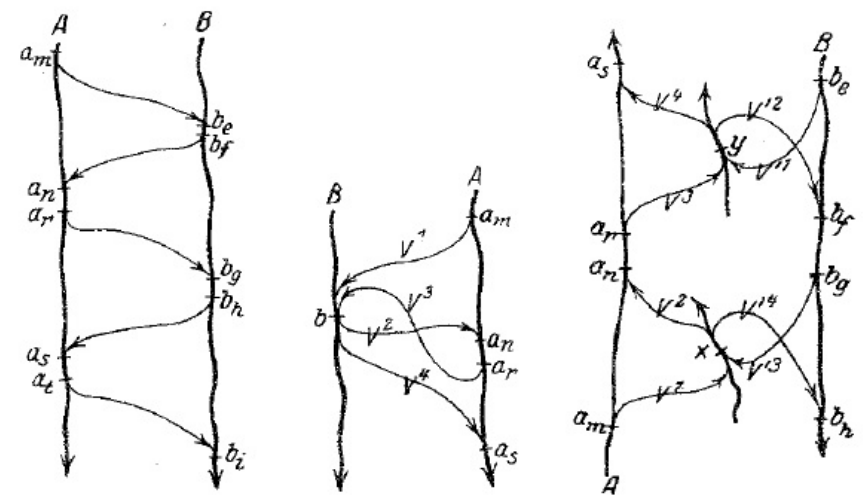

Fig. 2: Connection between series via "Botenzüge", Lewin (1923a, 75).

loops.

Intuitively, we can take the extension to the genetic series of succession to cover cases in which there are constructs (Gebilde) that are properly speaking not derived from a certain sequence, but that can be temporally related to it provided that a continuous chain of genetic series makes their connection effectual. This specification allows Lewin to articulate the temporal relations between concrete individual things or events historically ordered through their own temporal paths when they are (causally) interacting among themselves. Unconnected events can thus be correlated by a common (causal) series and this is the key to define a temporal order. Lewin's strong intuition is that such temporal determinations emerge only on the occasion of conjunctions and interactions of series, so that the structural features of the resulting net make possible the introduction of an objective and univocally defined time order. Besides, this net suffices to determine the direction of the causal chain. This is an element that Reichenbach will eventually appreciate in his "Die Kausalstruktur der Welt und der Unterschied von Vergangenheit und Zukunft" (1925).

We have seen that the comparison between series requires some sort of connecting device, of which a clock is an obvious realisation. Yet, the "Boten" are not to be reduced to the usual concept of a clock: this concept provides the additional feature of a coordination (Zuordnung) with the series of real numbers, a coordination which is not at all required in Lewin's model. In a footnote to this passage, Lewin explicitly refers to Reichenbach's "Bericht" (1921b) as an example of this type of coordination, interestingly adding that it follows the same line as Weyl's. ${ }^{35}$

\footnotetext{
${ }^{35}$ As he writes: "Auch Weyls Definition benutzt entsprechend der Absicht, für die Metrik verwendbare Uhren zu bestimmen, Genesereihen (und zwar restlose Genidentitätsreihen), deren
} 
In order to define a "system-time", in his (1921b) Reichenbach does indeed introduce a notion of "clock". However, he still considers it fulfilling a purely topological function, being an auxiliary concept devoid of metrical meaning and valid for any arbitrary metric. Reichenbach's "topological clock" is thus described as any mechanism with no specific material characterisation "that coordinates each event to a point according to the sequence of real numbers". ${ }^{36}$ Even so, in Lewin's view such a move already entails one step further into a more complex stage, where specific properties of physical processes (like a physical system having a cyclical period) do play a role. According to the psychologist, such a step is not necessary and can indeed be dispensed with within his own construction-at least given his project: a purely topological description of time order without any definition of or reference to simultaneity. The character of this topological relation is such that a comparison among cuts and intervals of unconnectible series of events is excluded by definition. No temporal determinations can be given between separate series unless metrical considerations come into play. So, the concept of simultaneity is bound to not fit this construction, which would render it meaningless. ${ }^{37}$

The temporal metric necessarily presupposes the study of the existential relations between series, and conversely this study is supplemented by the metric in two respects: on the one hand, it is only by virtue of the metric that we can speak of temporal relations expressed by numbers; on the other, the metric allows us to consider relations of temporal lengths.

Lewin's framework embodies the very general type of structural relations that can be evinced only on the basis of the existential relation that genidentity implies. In that sense, Reichenbach's use of the concept of "first signal", as we shall see, does not represent anything more than a token case-comparable to the genealogical sequences in biology - of this most general type of relation. Lewin's construction should, therefore, be interpreted like a foundation for Reichenbach's, who still uses relations derived from characteristic properties (Eigenschaftsbeziehungen) of a particular physical process (a light signal). What makes the notion of the signal operative is precisely the net of which Lewin has formalised the structural properties.

Most likely, Lewin's background in psychology and hence viewpoint from

Schnitte spezielle physikalische Eigenschaftsbeziehungen zeigen, wie sie in der zeitlichen Geneseordnung außer Ansatz bleiben.” Lewin (1923a, footnote 1 to p. 79).

${ }^{36}$ Reichenbach (1921b/2006, 47).

37 "Die Beschränktheit der zeitlichen Geneseordnung gegenüber der gewöhnlichen Zeitordnung zeigt sich darin, daß sie die Ordinalbeziehung nur zwischen zeitverschiedenen Ereignissen zu bestimmen gestattet (also nur die Beziehungen "früher" und "später", aber nicht die "Gleichzeitigkeit" getrennte Ereignisse) und die Zeitlängenbeziehung nur zwischen Geschehnisreihen, von denen die kürzere ganz "innerhalb derselben Zeit" stattfindet muß wie die längere, jedoch nicht zwischen Genesereihen, die ganz zu verschiedenen Zeiten stattfinden.” Lewin (1923a, 78). 
which he studied the notion of genidentity granted him a more general perspective on the whole issue than Reichenbach. Conversely, the very specialised context in physics in which Reichenbach worked made him unable to see the form of primordial relations analysed by Lewin, which lay below his alleged "elementary facts". In the next subsection, we will see how Reichenbach understands his model, his objections to Lewin, and their consequent discussions.

\subsection{From Genidentity to the Mark Principle}

\subsubsection{Genidentity in Reichenbach's Early Works}

The term "genidentity" is introduced by Reichenbach in his Habilitation thesis, Relativitätstheorie und Erkenntnis apriori (1920), where it appears in the form of an a priori principle of cognition. The philosophical background of this monograph is particularly important, so let us just briefly recall one of its central features, the suggested "liberalised" version of Kant's synthetic a priori. In this writing, Reichenbach still defends the idea of constitutive, yet revisable a priori principles of knowledge and accordingly proposes a distinction between axioms of connection and axioms of coordination. ${ }^{38}$ The axioms of coordination are related to the conceptual part of knowledge and are constitutive of the concept of physical object in that they determine the meaning of the axioms of connection, the laws of physics. Thus, they determine the rules of their application to reality, i.e., the rules of the connection. The specificity of genidentity as a constitutive principle is that of allowing us to indicate "how physical concepts are to be connected in sequences in order to define 'the same thing remaining identical with itself in time'." 39 As an example, Reichenbach mentions the fact that when we speak of the path of an electron, we have to consider it as the selfsame object through the passage of time. In other terms, we assume its identity through time, and therefore make use of the principle of genidentity as a conceptual presupposition. To be sure, among the cognitive principles, the principle of genidentity (like that of probability) plays a specific and most fundamental role. Being in fact presupposed by a number of other coordinating principles-especially those related to the process of measuring - genidentity seems to involve a higher level of coordination. As such, it is a condition of the possibility for utilising other principles and, therefore, appears to have a "meta-constitutive" function. ${ }^{40}$

As previously mentioned, when introducing this term in his (1920) Reichen-

\footnotetext{
${ }^{38}$ In recent years, Reichenbach's conception of the cognitive principles has been increasingly discussed after Michael Friedman's attempt to revive his original idea. See Friedman (2001) and references therein.

${ }^{39}$ Reichenbach $(1920 / 1965,53)$.

${ }^{40}$ On these aspects, see Padovani (2011).
} 
bach makes explicit reference to Lewin's Die Verwandtschaftsbegriffe in Biologie und Physik und die Darstellung vollständiger Stammbäume (1920), where genidentity is not considered. In the same year, Reichenbach writes a review of this essay, very much appreciative of the analytical methodology used by the author in the prospect of a positive turn in the philosophy of natural sciences. ${ }^{41}$ Despite that title, he points out, the idea of a genetic series in physics is not examined by Lewin in this early essay. Reichenbach accordingly argues that also in physics there are certainly interesting examples of genetic series-like those representing the existence of a material thing in time, i.e., the world line of a material pointunfortunately not treated by Lewin (1920). ${ }^{42}$ However, as we have seen in the previous section, Lewin's idea is actually that the world line of a material point is contingent, so to speak, on the genetic series, which is expressed by the existential relation embodied by the concrete events' persistence through time. Reichenbach, to the contrary and from the outset, tends to interpret the genetic series tout court as the world line.

In 1921, Reichenbach starts working on an axiomatisation of Einstein's theory of space and time, which he will finally achieve in his Axiomatik (1924a). He will write a brief report on the occasion of the famous Bad Nauheim meeting of the German Society of Natural Scientists in 1921. In this "Bericht" (1921b), Reichenbach proposes the idea of a light geometry, a geometry based on the physical properties of light and world line of a material point, independently of any relation to other material objects. One crucial feature of this project is the distinction between light and matter axioms. The first ones define the light geometry whereas the second ones "imply the identity of the developed 'light geometry' with the space-time theory of rigid rods and clocks". ${ }^{43}$ The other fundamental trait of this report is epistemological in nature and entails a first step towards conventionalism by drawing a clear-cut distinction between empirical axioms and arbitrary coordinative definitions. Finally, synthetic a priori principles are no longer considered

\footnotetext{
${ }^{41}$ Reichenbach (1921a). Here, he also correctly indicates the forthcoming volume Der Begriff der Genese. At the end of 1920, Lewin read a draft of this review before it was sent to the editor of the journal. Later, he wrote to Reichenbach in order to clarify some crucial points of his comparative approach. In the first phase of this correspondence, the point at issue was Reichenbach's (mis)understanding of the intrinsic difference among the notions of genetic series used in the various sciences - a difference which cannot be reduced to each science's degree of development, as Lewin made clear: "Es liegt mir an und für sich sehr am Herzen, zu betonen, dass der Unterschied der genetischen Reihentypen in Physik und Biologie nicht auf dem verschiedenen Entwicklungsgrad dieser Wissenschaften beruht[, vielmehr grade etwas ist, was in der Einstellung einer Wissenschaft konstant bleibt.] 2 Sätze in den Referat könnten nun leicht dahin missverstanden werden, dass gerade dies meine Meinung ist.” ASP, HR 015-57-14, Lewin to Reichenbach, 23 December 1920. Reichenbach must have changed his review accordingly.

${ }^{42}$ Reichenbach (1921a, 51).

${ }^{43}$ Reichenbach $(1921 \mathrm{~b} / 2006,46)$.
} 
and are turned into conventional definitions-as a matter of fact, a conceptual shift that is quite problematic for some "meta-constitutive" principles like genidentity. In Reichenbach's view, this geometry has an important advantage over other physical geometries, as he explains in a letter to Moritz Schlick in January 1922:

"I think that especially the axiomatic analysis will be of interest to you. It provides a validation of conventionalism, but it clearly reveals those facts that also conventionalism cannot interpret. Particularly remarkable is the fact that it allowed for the complete elimination of rigid rods and clocks. I managed to define the entire metrics simply by using light signals. This is of course also a real definition, but one can actually show that light suffices as reality, it even enables to define rigidity." 44 Reichenbach to Schlick, 18 January 1922 (Schlick Collection)

While in this brief report the light signal is taken as the basis of the definition of time order, ${ }^{45}$ in the Axiomatik the axioms of time order will have another starting point, the following definition:

"Definition 1. Of two events $E_{1}$ and $E_{2}$ happening at $P$, the event $E_{2}$ is called later than $E_{1}$ if a signal chain can be chosen in such a way that its departure coincides with $E_{1}$ and its return with $E_{2}$. In this case, $E_{1}$ is called earlier than $E_{2}$.

Axiom I, 1. There is no signal chain such that its departure and its return coincide at $P$. . Reichenbach $(1924 a / 1969,29)$.

With the help of what will be later known as the "mark principle", Reichenbach clarifies the notion of light signal: a light signal is a physical process or event traveling from a point $P$ to a point $P^{\prime}$ and having the property that when this event

\footnotetext{
44"Ich glaube, dass die axiomatische Analyse Sie besonders interessieren wird. Sie liefert natürlich eine Bestätigung des Konventionalismus, aber sie deckt auch jene Tatsachen auf, an denen auch der Konventionalismus nicht interpretieren kann. Besonders merkwürdig ist es, dass es möglich war, die starren Massstäbe u. Uhren völlig zu eliminieren. Ich konnte allein durch Benutzung von Lichtsignalen die ganze Metrik definieren. Das ist natürlich auch eine Realdefinition, aber es zeigt sich eben, dass das Licht als Realität genügt, es vermag sogar die Starrheit zu definieren." Reichenbach to Schlick, 18 January 1922 (Schlick Collection).

45"1. Axioms of time order. We first define the time order at a point. A light signal sent from a point $A$ to an arbitrary point $B$ (which may be moving) is reflected and returns back to $A$. Definition 1. The departure of the signal from $A$ is called "earlier" (written $<$ ) than its return to $A$." Reichenbach $(1921 \mathrm{~b} / 2006,46)$. I shall point out that Reichenbach does not seem to be acquainted with a similar attempt to define the temporal order carried out by the mathematician Robb already in his A Theory of Time and Space (1914).
} 
is marked at $P$, the mark will also be observed at $P^{\prime}$. In this case, "the word 'signal' pinpoints this very property because it means a transmission of a sign. The word 'causal chain' is also frequently used in such instances". ${ }^{46}$ The physical world consists of causal chains, whose structural relations can be formulated as topological and metrical axioms. Metrical axioms are statements about certain topologically specified chains (or first signals). Topological axioms are statements defining time order and concerning the possibility of connecting all space points by causal chains. The topological axioms defining time order assert that no causal chain is closed. If we possess a time order, it is indeed thanks to the causal chain. Thus, time provides the description of "an objective state of the physical world just like any other scheme of order-for instance, genealogical order." So, he concludes, "time is the order type [Ordnungstypus] of causal chains." sion to the genealogical order and to the notion of "Ordnungstypus" is clearly an echo of Lewin's work (not mentioned at this point, by the way) but it is not developed here. Instead, it will be developed in his essay on the theory of motion in Newton, Leibniz and Huygens (1924b), published in the same year. In the analysis of the Leibniz-Clarke correspondence, Reichenbach takes Leibniz's reference to genealogy as an opportunity to discuss the parallelism between genealogical and causal order, eventually citing Lewin:

"In a genealogical order, every individual has a 'place', and exactly as in a spatial order the place of an individual indicates nothing but certain relations he bears to other individuals. [...] The genealogical order schematizes the structure of ancestral relations between individuals, and is not something else existing in addition to this structure. [...] According to the investigations by K. Lewin, we may regard the genealogical order as the space-time order of biological evolution, in exactly the same sense as we have to regard the causal order as the space-time order of physics.” Reichenbach (1924b/1959, 54-55).

As I pointed out before, genealogical sequences are comparable to light signals in the sense that they both represent a token case of the more primordial structure type expressing the actual, temporal (i.e., causal) order, which Lewin has constructed in his (1923a).

Probably to avoid any Kantian overtones, the notion of genidentity no longer appears in Reichenbach's Axiomatik. Its role is transferred onto the mark principle that he defines only after introducing the notion of light signal. Direct reference to genidentity and its fundamental significance will be made explicitly in Die Philosophie der Raum-Zeit-Lehre (1928). The return to the concept of genidentity

\footnotetext{
${ }^{46}$ Reichenbach (1924a/1969, 27).

${ }^{47}$ Reichenbach (1924a/1969, 15-16).
} 
will be the result of an exchange with Lewin, but will not be without consequences from a philosophical point of view, as I shall briefly highlight in the concluding section. Let us first analyse their correspondence.

\subsubsection{Reichenbach's Correspondence with Lewin}

Reichenbach and Lewin were very close friends and colleagues. Most likely, Reichenbach informed Lewin about the larger manuscript on the axiomatics of time on which he was working in that period. In his first letter related to the topic of the topology of time, dated 17 March $1922,{ }^{48}$ Lewin addressed Reichenbach to thank him for sending his "Zeitaxiomatik", 49 and for informing him of the progress of his work about the genidentical series. ${ }^{50}$

The following letter, sent in September 1922, accompanied a copy of the manuscript of "Die zeitliche Geneseordnung" (1923a), which to Lewin's mind represented "a good completion" (eine ganz gute Ergänzung) of Reichenbach's axiomatics of time. In the diplomatic terms used by Lewin, this "completion" actually meant a clarification of the lacking elements of Reichenbach's topological foundation. Lewin deemed in fact his approach to be starting from the most fundamental level of analysis, differently than Reichenbach's. As he wrote:

"I see which time order arises merely on the basis of the genetic series in terms of genidentical series. Thereby, I would like to desist from presupposing formally the concept of 'simultaneity' in the definition of 'complete' genidentity. [...] Yet, I would like to take the genetic series as a basis by emphasising its peculiarity, and not to use any specific 'relation of property or of magnitude'. The question is how far I can go simply on the ground of the existential relation of the genetic series. I obtained a 'general time order' of very limited use, which involves relations of time length (that are of course only of 'topological' nature, here). On the other hand, it is of very general nature because it does not make any assumptions about constancy, velocity or physical kinds of events, 'reference systems' or carriers, and constitutes a foundation of any factual determination of time. [...] Your axiomatisation treats just all the properties of time that I do not take

\footnotetext{
${ }^{48}$ The Pittsburgh Archives contain many letters from Lewin to Reichenbach, but unfortunately no replies have been found to the letters we are using in this section.

${ }^{49}$ This manuscript represents the first draft of the Axiomatik, which was originally supposed to be dealing more specifically with time. Cf. ASP, HR 023-35-01.

${ }^{50}$ As he wrote: "Ich bin dabei, mir die Beziehungen zum Genidentitätsreihenbegriff zu überlegen. [...] Die Stellung der Zeit als Parameter der genetischen Reihen löst vielleicht gewisse Schwierigkeiten, die beim Gedanken des Raumpunktes bestehen.” ASP, HR 015-57-13, Lewin to Reichenbach, 17 March 1922.
} 
into consideration." ${ }^{2}$ ASP, HR 015-57-12, Lewin to Reichenbach, September 1922.

This motivation notwithstanding, Reichenbach criticised Lewin's proposal in his Axiomatik. His disagreement is basically centred around the concept of signal and the corresponding definition of simultaneity, and it results in two footnotes, one in $\S 5$ ("The Concepts of Real Point and Signal") and the other in $§ 7$ ("Axioms of the Comparison of Time").

In the first footnote, Reichenbach mentioned Lewin after introducing the definition of signal as a physical process of "sign transmission" that we have seen above: ${ }^{52}$

"In earlier presentations I started with light signals. The validity of theorem 9 for any real events then follows from the fact that the light signal $P P^{\prime}$ arrives at $P^{\prime}$ earlier than any other signal departing simultaneously from $P$ (limiting character of the velocity of light). K. Lewin drew my attention to the fact that all properties of signals can be formulated directly for any signal (Zeitschr. f. Phys., vol. 13 [1923], p. 62). Starting from differently oriented investigations concerning genealogical sequences, Lewin (Begriff der Genese [Berlin: Springer, 1922]) arrived at a conception of time order similar to mine." Reichenbach (1924a/1969, 27).

As in (1924b), Reichenbach correctly associates the outcomes obtained by means of his notion of signal with Lewin's genealogical sequences. Yet, it is clear that Reichenbach keeps considering his own level as the most elementary, and that he

\footnotetext{
51 "Ich sehe zu, welche Zeitordnung ergibt sich lediglich auf Grund der Genesereihen im Sinne der Genidentitätsreihen. Dabei möchte ich davon absehen, dass ich bei der Definition des Begriffs der "restlosen" Genidentität formal den Begriff der "Gleichzeitigkeit" voraussetze. [...] Sondern ich möchte die Genesereihe zugrundelegen unter Betonung ihrer Eigenheit, keine bestimmten "Eigenschaft-" oder quantitativen "Grössenbeziehungen" zu verwenden. Die Frage lautet, wie weit komme ich auf Grund lediglich der Existentialbeziehung der Genesereihen. Ich erhielt eine "allgemeine Zeitordnung" von sehr beschränkter Anwendung, was Zeitlängenbeziehungen (die hier natürlich nur "topologischer" Natur sind) betrifft. Anderseits ist sie sehr allgemeiner Natur, weil sie keine Annahmen über Konstanz, Geschwindigkeit oder physikalische Art der Ereignisse, "Bezugssysteme" oder Boten macht und bildet so eine Grundlage für jede faktische Zeitbestimmung. [...] Ihre Axiomatik geht ja gerade auf alle die Eigentümlichkeiten der Zeit, die ich ausser Acht lasse.” ASP, HR 015-57-12, Lewin to Reichenbach, September 1922

${ }^{52}$ As he points out in the previous footnote, the fact is that there is an epistemological problem related to the concept of mark. Interestingly, here, Reichenbach writes that "for our purposes the concept of ordinary language suffices. This concept indicates already that the mark at $P^{\prime}$ is not exactly the same as the mark at $P$, but shares only certain fundamental features. The mark may be distorted (sounds over the telephone). We shall leave open the question of whether a reference to the concept of Gestalt is necessary." Reichenbach (1924a/1969, 27).
} 
holds his notion of signal to be comparable to Lewin's genetic series. However, as we have seen, in Lewin's work the genetic series provide a primordial level of analysis that is meant to be more fundamental than Reichenbach's-a point that Reichenbach doesn't seem to be willing to admit at this point. ${ }^{53}$

Theorem 9, presented a few pages later, presupposes all previously defined topological axioms of the time order and the comparison of time, and it asserts that simultaneity can be defined from a purely topological point of view "in such a way that a continuous positive time interval is assigned to every physical process (signal, causal chain)", that is, provided that a univocal coordination be established between the order of temporal sequences and the sequence of real numbers (Theorem 2). Theorem 9, according to Reichenbach, "contains the most important topological problem of simultaneity. Only this theorem permits the consistent application of definition $1^{54}$ in a uniform continuous order of time." 55

The second footnote where Lewin is mentioned by Reichenbach follows this attempt to show that his own definition of simultaneity is of a topological and not of a metrical nature. We have seen that Lewin deemed this kind of coordination to already imply a step beyond the purely topological dimension, and that it was therefore not to be regarded as so fundamental as his. However, Reichenbach contended that Lewin was mistaken in regarding simultaneity as a metrical determination.

"This is the reason—-he argued—why [Lewin] misrepresents my earlier investigation, ${ }^{56}$ which also begins with the topological problem of time; in this publication axioms I and II are topological axioms. The clock introduced by definition $2^{57}$ has only topological qualities because of the arbitrariness of the metric. The difference between Lewin's investigations and my own lies in another direction, as was revealed in a personal discussion: whereas my axioms make assertions about all physically possible signals and my 'there exist' means 'except for technical difficulties they can be produced experimentally', Lewin restricts himself to assertions about actual signals and does not speak of possible ones. Therefore, Lewin's investigation cannot (and will not) go as far as mine, not even topologically. Above

\footnotetext{
${ }^{53}$ As he makes clear, "[t]hat signals exist, that we can produce them, send them to a given real point, combine them, and reflect them are elementary facts [elementare Tatsache]; axioms I and II contain everything concerning these facts that is necessary for the construction of the order of time." Reichenbach $(1924 a / 1969,28)$.

${ }^{54}$ See above, footnote 45.

${ }^{55}$ Reichenbach (1924a/1969, 39).

${ }^{56}$ Reichenbach (1921b).

${ }^{57}$ In the Bericht, Definition 2 is the first one of the second group of axioms, those regarding the comparison of time, which include the above-mentioned definition of the topological clock.
} 
all, the concept of first signal cannot occur in the sense of a limit. Cf. Lewin's report about his studies in Physikalische Berichte [Lewin (1923c)]." Reichenbach (1924a/1969, 39).

At the beginning of 1924, Reichenbach sent the final draft of the Axiomatik to his colleague in Berlin. In a letter of clarification, Lewin strongly emphasised, once more, that his topology represented a supplement to Reichenbach's, and was definitely neither a substitute nor a similar attempt of limited application. This is a positive aspect in Lewin's standpoint that Reichenbach continued not to be willing to concede. Certainly, as Lewin remarked, the distinction between the topological and the metrical must be regarded as secondary with respect to the distinction between actual and possible. But it is precisely the latter, along with the fact that Lewin deals with the actual order derived by genidentical series, that rendered his approach more fundamental and not just alternative, as he clarified in the above-cited report on his own work published in the Physikalische Berichte in autumn $1923 .{ }^{58}$

There, Lewin presents the essential elements of his topology of time, namely the fact that temporal relations can obtain from actual processes and lead to a definition of temporal order if we simply consider, in mereological terms, the formations or events that follow one from the other by means of the existential sequences. The peculiarity of this definition of temporal order is that it does not depend on the specific physical nature of the genetic series connected, or whether, for instance, we are talking about light or matter transport. Once more, Lewin underlines that no consideration of speed, measure or proportion between physical values or even of simultaneity between sections of sequences is taken into account. In this sense, any change in the genetic series taken as reference does not affect the topological relations derived. So, he concludes, each metrical temporal determination (including the ones defined by the theory of relativity) should in principle presuppose his more basic approach, the only one leading to the fundamental structural net of temporal relations. ${ }^{59}$

\footnotetext{
58“Ich habe leider die Arbeit in den beiden Tagen noch nicht sehr eingehend studieren können und daher im wesentlichen die Anmerkungen gelesen. Ich glaube, es ist Ihnen noch nicht ganz deutlich geworden, dass ich wirklich eine gegen Ihre Axiomatik beträchtlich verschiedenes Ziel verfolgt habe. Dass der Unterschied: topologisch-metrisch sekundär ist gegenüber dem Unterschied: wirklich-möglich kommt schon in meinem Eigenbericht [Lewin (1923c)] in den Physik. "Berichten" zum Ausdruck, den ich Ihnen beilege (bitte zurücksenden!!). Dass meine zeitliche Geneseordnung weniger weitreichend ist als alle auf "Möglichkeiten" bezugnehmende Zeitordnungen, habe ich ja immer zu betont. Es ist also irrefürend, von "nicht erschöpfend" zu reden! Denn diese Beschränkung auf das "Wirkliche" gibt der zeit[lichen] G[enese]-Ordnung m. E. ja gerade die Fundamentalität gegenüber allen auf "Möglichkeiten" bezugnehmenden Ansätzen." ASP, HR 016-36-13, Lewin to Reichenbach, 24 January 1924.

${ }^{59}$ Lewin $(1923 c, 977)$.
} 
Lewin's letter dated January 1924 goes along the same line and in order to avoid further misunderstandings accordingly presents a list of suggested corrections to the two footnotes where his work is mentioned in Reichenbach's axiomatisation. As far as the first one is concerned, Lewin notes that his notion of signal does not correspond to the one used by Reichenbach, especially since he does not need the additional property provided by the mark principle, already implied by the concept of genetic series. ${ }^{60}$ Clearly, Reichenbach originally understood the genetic series as having the limited character of some existential connections that for no reason can ground an axiomatic account of the topology of time, which up to this moment he still interprets as regarding only possible-i.e., not necessarily actual, contrary to Lewin-connections. As Reichenbach points out in the second footnote, the divergences between them relate to the kind of events they want to account for. In his letter, Lewin correspondingly spells out their specificity:

"In the footnote to p. 63 of my work, which you are most likely referring to, I did not talk about the metrical character of your work, but, rather, about the fact that you make use of property relations. This applies in any case at least to the light signals. And even now, for instance with Axiom I, $2^{61}$ you still make assumptions about certain say quasi-continuous distributions of the physical reality (without which that axiom, as far as I can see, would not hold for a finite velocity of the signals). In principle, [these distributions] derive from the sphere of conditions of the temporal order of the genesis. [...] The earlier version appears to assign the temporal order of the genesis purposes that it does not have. Also, I have always explicitly stressed ([1923a,] p. 80 bottom) that it is possible to say more from a topological point of view with the help of a (variable or constant) metrics." ${ }^{2}$ ASP, HR

\footnotetext{
60“Ad Anmk. S. 20: 'der freilich — beschreibt.': streichen! Ich sehe nicht den Sinn des Satzes, da ich gar nicht eigentlich von "Signalen" in Ihrem Sinne rede, z. B. brauche ich nicht die Erkennbarkeit der Eigenschaft des Signals $P P^{\prime} P$, dass es $P^{\prime}$ erreicht hat; resp. die fehlenden Eigenschaften sind ja durch die Definition als Genesereihen gegeben, deren Axiome in meinem Buch angegeben sind. Dort steht übrigens auch was von den "Kennzeichen" (S. 15 u. a.), wenn auch nur in Bezug auf feste Körper." ASP, HR 016-36-13, Lewin to Reichenbach, 24 January 1924.

${ }^{61}$ Axiom I,2 is the axiom of connection of temporal series and it is so defined: "Axiom I, 2. For any two events $E_{1}$ and $E_{2}$ at $P$ there exists always a signal whose departure coincides with $E_{1}$ (or $E_{2}$ ) and whose return coincides with $E_{2}$ (or $\left.E_{1}\right)$." Reichenbach $(1924 \mathrm{a} / 1969,30)$.

${ }^{62}$ Ich habe in Anmk. S. 63 meiner Arbeit, die Sie offenbar meinen, nicht von dem metrischen Charakter Ihrer Arbeit gesprochen, sondern davon, dass Sie "Eigenschaftsbeziehungen" mitbenutzen. Das traf auf die Lichtsignale zumindest auf jeden Fall zu. Und auch jetzt machen Sie z. B. mit Axiom I,2 noch Annahmen über gewisse, sagen wir quasikontinuierliche Verteilungen der physikalischen Realität (ohne die das Axiom, soviel ich sehe, bei endlicher Geschwindigkeit der Signale nicht gelten würde), die über die Voraussetzungssphäre der zeit[lichen] G[enese]-Ordnung
} 
016-36-13, Lewin to Reichenbach, 24 January 1924.

According to Lewin, making use of light signals as the starting point of a topological account of time actually calls for more analyses concerning the specific properties of the physical process assumed as the elementary fact. This fact already entails a further level of elaboration in comparison to his own "minimalist" topological approach, let alone the introduction of a "topological clock" in order to define simultaneity. Thus, with his topological construction Lewin obtains much with a restricted number of assumptions (namely, only the assumption of genidentity as an existential relation), whereas Reichenbach has to introduce light signals supplemented by the mark principle, virtually presupposing all the considerations about genidentity explored by Lewin without using any concept of clock.

Despite what he wrote to Schlick in the missive we have seen above, Reichenbach neither provided the most basic account, nor did he accept Lewin's criticism concerning the unanalysed assumptions upon which his construction actually rests.

\section{Reichenbach's Return to Genidentity}

Reichenbach adopted a different perspective in his innovative work "Die Kausalstruktur der Welt" in 1925, when he eventually started formalising the causal correlations between actual series of events and applied his probabilistic approach to Lewin's topological model in order to define the direction of time. The idea here was to develop a topological account of the probabilistic implications that can be obtained starting from an analysis of the behaviour of interacting causal chains. Most importantly, now Reichenbach puts forward-clearly influenced by Lewin-a description of the causal processes in terms of nets. It is in fact in this paper that, for the very first time, he uses the so-called fork asymmetry account, which he will amend and improve only at the end of his life, in The Direction of Time (1956). In its basic form, this 1925 account relies quite consistently on Lewin's analysis of the splitting and intersecting series, which we have seen above. Following Lewin, here Reichenbach emphasises that only the relations between actual events belonging to different series can provide a good ground for identifying the direction of causal chains. The direction of time "can first be

prinzipiell hinausgehen. [...] Die alte Fassung scheint der z[eitlichen] G[enese]-O[rdnung] Absichten unterzulegen, die sie nicht hat. Auch dass man mit Hilfe einer (variabel oder konstanten) Metrik topologisch mehr aussagen kann als die z[eitliche] G[enese]-O[rdnung], habe ich selbst ausdrücklich hervorgehoben (S. 80 unten)." ASP, HR 016-36-13, Lewin to Reichenbach, 24 January 1924. 
gained with the emergence of connecting points. In this way we are led to base the temporal order upon the characteristics of a net structure." 63

After this "turn", the principle of genidentity will reappear in all its significance in Die Philosophie der Raum-Zeit-Lehre (1928), where it is regarded as a fundamental axiom, but of empirical nature. Let us recall that Reichenbach's causal chains presuppose, at the more primordial level highlighted by Lewin, some form of genidentity as a condition of their definability. In his famous book of 1928, Reichenbach refines some of the issues involved by the consideration of causal chains and the related notion of genidentity. Different states can be genidentical only if they are causally related. As he explains, "this conception agrees with our definition of causal connection, which considers the causal chain a signal, i.e. the transmission of a mark". ${ }^{64}$ In the section devoted to the definition of time order, Reichenbach insists in particular on the necessity of considering the causal chains open, and he addresses the question whether closed causal chains could occur or even merely be imagined at all. Although this could not be excluded a priori, he points out that the uniqueness of time order as well as our familiar concept of identity through time of the individual would be lost. The properties of the causal chains fundamentally underlie our concept of individuality, and this concept, Reichenbach goes on, "originates in the fact that there are no closed causal chains" (p. 142). If the causal chains were closed, the principle of genidentity would be violated, and we should admit cases in which a person could meet his/her former self. However, this has never been observed and would moreover be rather difficult to accept. It is in fact our concept of individuality that requires that the causal chains be open. In other terms, genidentity must be assumed as a very deep principle of our physical knowledge (ein sehr tiefes Prinzip der Naturerkenntnis) because

"[i]t enables us to speak of a unique time order and a unique nowpoint. Furthermore, it makes possible the concept of the individual that remains identical during the passage of time. It is therefore the most important axiom regarding time order, and we realise to what an extent the familiar concept of time order is based on this characteristic of causality. Of course, this axiom is a result of experience [es ist klar, daß es sich in diesem Axiom um einen Erfahrungssatz handeln kann]." Reichenbach (1928/1958, 142-143).

This principle is a fundamental presupposition of our knowledge for it allows us to preserve our most important concept of individuality. Despite its funda-

\footnotetext{
${ }^{63}$ Reichenbach $(1925 / 1978,93)$. Due to space limitations, we cannot follow these issues in detail here, nor can we follow the fate of genidentity in (1956) where genidentity still plays a central role.

${ }^{64}$ Reichenbach (1928/1958, 271).
} 
mental role, Reichenbach would say, it cannot be considered necessary as there cannot be necessary principles in nature. Nor can we take it to be a convention. Thus, Reichenbach labels it as an "empirical principle". The justification is by exclusion and in line with his shift towards conventionalism. Since genidentity, as a principle, cannot be deemed to be conventional, nor can it be interpreted as a methodological assumption, it must be empirical. In this way, the risk of interpreting it as an otherwise inexplicable principle is seemingly avoided. Yet, this justification clearly sounds quite artificial. To be sure, the principle of genidentity really looks like an anomalous principle within this framework and to define it as a mere empirical principle would not explain why we rely on it as a principle grounding our notion of individuality, as Reichenbach emphasises. In this sense, as a (temporary) condition of possibility of our knowledge of nature, it still has the same features it used to have when it was introduced in Relativitätstheorie und Erkenntnis apriori (1920), namely those of a synthetic, yet revisable a priori principle - which is tantamount to reintroducing constitutive principles by the back door.

\section{Acknowledgements}

Research for this paper was variously supported by a Swiss Research Fellowship from the Canton of Ticino, as well as by a grant from the Swiss National Science Foundation (PA00P1-134177). Early versions of this paper were presented at several conferences including the conference "The Berlin Group: Knowledge Probability, Interdisciplinarity" held in Paderborn in September 2009, and to the Visiting Fellows' reading group at the Center for Philosophy of Science at the University of Pittsburgh in Spring 2009. On both occasions, I have greatly benefitted from the remarks made by the audience, especially the invaluable suggestions from Chris Pincock and Ulrich Krohs. I am also grateful to Sheila Sandapen, Joe McPeak, and Jacques Catudal for comments on a more recent draft of this paper. Finally, I wish to thank both the Directors of the Archives of Scientific Philosophy in Pittsburgh and Konstanz, and of the Wiener Kreis Stichting in Amsterdam for their permission to quote from the Hans Reichenbach and the Moritz Schlick Collections. My special thanks goes to Brigitte Parakenings from the Konstanz Archives for her help in supplying unpublished material.

\section{References}

[1] Ash, M.G. (1995). Gestalt Psychology in German Culture, 1890-1967: Holism and the Quest for Objectivity. Cambridge: Cambridge University 
Press.

[2] Cassirer, E. (1910). Substanzbegriff und Funktionsbegriff. Untersuchungen über die Grundfragen der Erkenntniskritik. Berlin: Bruno Cassirer. Translated as Substance and Function. Chicago: Open Court, 1923.

[3] Friedman, M. (2001). Dynamics of Reason. Stanford: CSLI Publications.

[4] Gerner, K. (1997). Hans Reichenbach. Sein Leben und Wirken. Osnabrück: Phoebe Autorenpress.

[5] Lewin, K. (1920). Die Verwandtschaftsbegriffe in Biologie und Physik und die Darstellung vollständiger Stammbäume. Berlin: Borntraeger.

[6] Lewin, K. (1922). Der Begriff der Genese in Physik, Biologie und Entwicklungsgeschichte. Berlin: Springer. Repr. in Lewin (1983), 47-304.

[7] Lewin, K. (1923a). Die zeitliche Geneseordnung. Zeitschrift für Physik 13:62-81.

[8] Lewin, K. (1923b). Berechtigung. Zeitschrift für Physik 15:64.

[9] Lewin, K. (1923c). Kurt Lewin, Die zeitliche Geneseordnung. Physikalische Berichte 4:977.

[10] Lewin, K. (1925). Über Idee und Aufgabe der vergleichenden Wissenschaftslehre. Symposion 1 (1):61-94.

[11] Lewin, K. (1983). Kurt Lewin: Werkausgabe. Wissenschaftstheorie II. Graumann, C.-F. \& A. Métraux (eds.), Bern-Stuttgart: Huber-Klett-Cotta.

[12] Marrow, A.J. (1969). The Practical Theorist: The Life and Work of Kurt Lewin. New York-London: Basic Books.

[13] Métraux, A. (1992). Kurt Lewin: Philosopher-Psychologist. Science in Context 5 (2):373-384.

[14] Padovani, F. (2011). Relativizing the Relativized A Priori. Reichenbach's Axioms of Coordination Divided. Synthese 181 (1):41-62.

[15] Reichenbach, H. (1911a). Universität und Technische Hochschule. Ein Vergleich. Berliner Freistudentische Blätter 4 (16):243-247.

[16] Reichenbach, H. (1911b). Universität und Technische Hochschule. Berliner Freistudentische Blätter 4 (20):310-312. 
[17] Reichenbach, H. (1916). Der Begriff der Wahrscheinlichkeit für die mathematische Darstellung der Wirklichkeit. Leipzig: Barth. Translated as The Concept of Probability in the Mathematical Representation of Reality, Eberhardt, F. \& C. Glymour (eds.). Chicago-La Salle (Ill.): Open Court, 2008.

[18] Reichenbach, H. (1920). Relativitätstheorie und Erkenntnis apriori. Berlin: Springer. Translated as The Theory of Relativity and A Priori Knowledge, M. Reichenbach (ed.). Berkeley-Los Angeles: University of California Press, 1965.

[19] Reichenbach, H. (1921a). Rezension von Kurt Lewin, Die Verwandtschaftsbegriffe in Biologie und Physik und die Darstellung vollständiger Stammbäume. Die Naturwissenschaften 9:51.

[20] Reichenbach, H. (1921b). Bericht über eine Axiomatik der Einsteinschen Raum-Zeit-Lehre. Physikalische Zeitschrift 22:683-686. Engl. transl. in Defending Einstein: Hans Reichenbach's Writings on Space, Time and Motion, Gimbel, S. \& A. Walz (eds.). New York: Cambridge University Press, 2006: 45-55.

[21] Reichenbach, H. (1924a). Axiomatik der relativistischen Raum-Zeit-Lehre. Braunschweig: Fried. Vieweg \& Sohn. Translated as The Axiomatization of the Theory of Relativity, M. Reichenbach (ed.). Berkeley-Los Angeles: University of California Press, 1969.

[22] Reichenbach, H. (1924b). Die Bewegungslehre bei Newton, Leibniz und Huygens. Kant-Studien 29:416-438. Engl. transl. in Modern Philosophy of Science: Selected Essays, Reichenbach M. (ed.). London: Routledge \& Kegan Paul, 1959: 46-66.

[23] Reichenbach, H. (1924c). Rezension von Kurt Lewin, Der Begriff der Genese in Physik, Biologie und Entwicklungsgeschichte. Eine Untersuchung zur vergleichenden Wissenschaftslehre. Psychologische Forschung 8:188190.

[24] Reichenbach, H. (1925). Die Kausalstruktur der Welt und der Unterschied von Vergangenheit und Zukunft. Sitzungsberichte der Bayerische Akademie der Wissenschaft, November: 1933-1975. Engl. transl. in Selected Writings: 1909-1953, Cohen, R. \& M. Reichenbach (eds.). Dordrecht-Boston: Reidel, 1978, Vol. II:81-119.

[25] Reichenbach, H. (1928). Philosophie der Raum-Zeit-Lehre. Berlin-Leipzig: De Gruyter. Translated as The Philosophy of Space and Time, Reichenbach, M. \& J. Freund (eds.). New York: Dover, 1958. 
[26] Reichenbach, H. (1956). The Direction of Time. Berkeley: University of California Press.

[27] Reichenbach, H. (1978). Selected Writings: 1909-1953. 2 Voll., Cohen, R. \& M. Reichenbach (eds.). Dordrecht-Boston: Reidel.

[28] Robb, A.A. (1914). A Theory of Time and Space. Cambridge: Cambridge University Press.

[29] Ryckman, T.A. (2007). Logical Empiricism and the Philosophy of Physics. In The Cambridge Companion to Logical Empiricism, Richardson, A.W. \& T. Uebel (eds.). New York: Cambridge University Press: 193-227.

[30] Smith, B. \& K. Mulligan (1982). Pieces of a Theory. In Parts and Moments. Studies in Logic and Formal Ontology, B. Smith (ed.), Munich: Philosophia, 15-109.

[31] Wipf, H.-U. (1994). 'Es war das Gefühl, daß die Universitätsbildung in irgend einem Punkte versagte...' - Hans Reichenbach als Freistudent 1910 bis 1916. In Hans Reichenbach und die Berliner Gruppe, Danneberg, L., Kamlah, A. \& L. Schäfer (eds.). Braunschweig: Vieweg: 161-181.

[32] Wipf, H.-U. (2004). Studentische Politik und Kulturreform. Geschichte der Freistudenten-Bewegung 1896-1918. Schwalbach/TS: Wochenschau Verlag. 